\title{
Proteomics and interactomics in grapevine: the next level in the study
}

\author{
Mária Čarnáa, b, Vladimír Repka ${ }^{\mathrm{b}}$, Ernest Šturdík \\ ${ }^{a}$ Institute of Biotechnology and Food science, Slovak University of Technology, \\ Radlinského 9, 81237 Bratislava, Slovakia \\ ${ }^{b}$ Slovak Academy of Science, Institute of Botany, Dúbravská cesta 9, 84523 Bratislava, Slovakia \\ maria.carna@stuba.sk
}

\begin{abstract}
To understand the cellular biology and biochemistry of plant cell behavior, there is not only one approach for studying proteins which are directly responsible for cellular activity. However, despite the enormous quantity of information generated by transcriptome analysis, the picture is still incomplete. The proteomic and interactomic approaches present a new point of view that so far has been missing. Comparative proteomics provide a powerful means to study products of genes and their regulation. On the other side, interactomes of different species can provide information about the evolutionary mechanisms leading to organism diversity. Then, this analysis allows scientists to better understand how complex biological processes are regulated and evolved.
\end{abstract}

Keywords: proteomics, interactomics, grapevine, habituation

\section{Introduction}

In the recent period of time, the major effort has been concentrated on microarray studies of mRNA expression and DNA sequencers of next generation, which can allow a global analysis of the mRNA complement (via cDNA) of any cell in the organism. On the other hand, it is well-known that gene expression is not regulated only on one level. Some kind of heritable traits and characteristics are not encoded in the sequences of DNA, but in other macromolecules (proteins, RNA molecules, etc.). The quantity of mRNA and its changes are not always shown at the corresponding protein level. A rapid change in the behavior of cells often rely on pre-existing proteins, which alter their sub-cellular localization by post-translational modifications and/or undergoing directed degradation. The other biologically relevant level includes genes encoding differently spliced mRNAs that can give rise to more than one protein (Quirino et al. 2010). This is evidence that many biological questions can be addressed at the level of protein, because several levels of gene expression regulation- epigenetic DNA modifications and amount of small non-coding RNAs are currently uncovered. For that reason, technologies for studying cell proteins are a welcome complement. The fast developments in the 'omics' area and the combination of different 'omics' tools offer great potential for post-genomic era to elucidate the genotype-phenotype relationships for both fundamental and applied research (Wienkoop et al. 2010).

In addition, proteomic data are beginning to be validated using complementary - omics or clas- sical biochemical or cell biology techniques, and appropriate experimental designs and statistical analyses are being carried out in accordance with the required standards of Minimal Information about a Proteomic Experiment (MIAPE). As a result, the coverage of the plant cell proteome and plant biology knowledge is increasing, but is still far from being minimally covered and validated (Jorrín-Novo et al. 2009).

Grapevine, like a long time cultivated and very important plant with high utility (juice, wine, liquors, source of antioxidants) was an object of many studies, but deeper knowledge of the changes in protein, which are responsible for majority of biological processes that affect not only fruit development but also general metabolism including defense responses is still missing (Giribaldi et al. 2010). From this point of view, many efforts have been devoted to discover and understand a protein synthesis in grapevine.

\section{Plant proteomics}

The "proteome" is derived from proteins expressed by a genome, cell, tissue or organism and it refers to all the proteins produced by an organism, much like the genome is the entire set of genes (Abhilash 2009). Proteomics profiling and imagining represent the universal study of the global protein content of a cell (proteome). This view presents new technical challenges due to their bigger structural complexity in comparison to that of nucleic acids. Technological progress in this approach can allow for a new perspective toward understanding how a cell works in general (Quirino et al. 2010). Proteom- 
ics, the comprehensive and quantitative analysis of proteome presents unique insights into biological systems that cannot be provided by genomic or transcriptomic approaches (Remmerie et al. 2011) (Fig. 1).

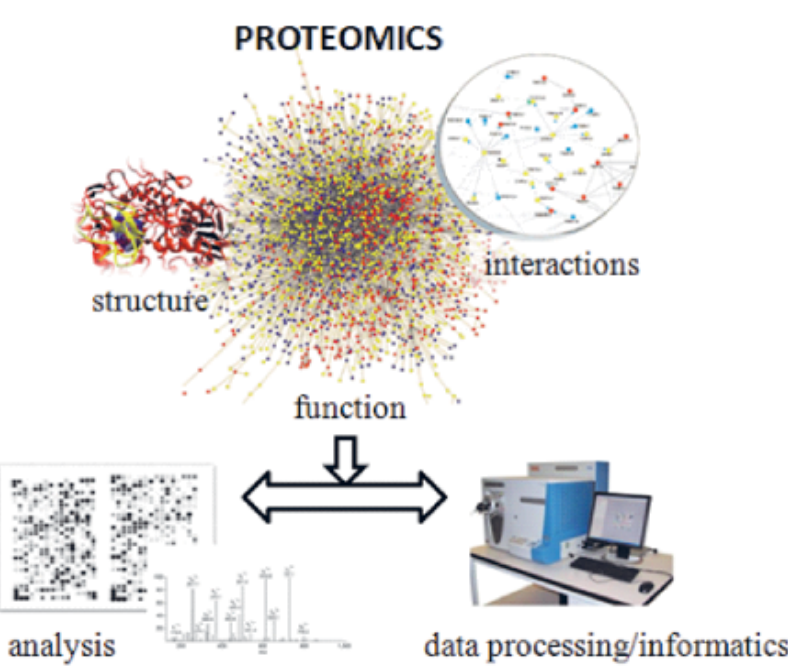

Fig. 1. Comprehensive and quantitative analysis of proteome (Siming et al. 2004).

Developmental proteomics can be defined as a set of proteins present at particular developmental stage of a plant. It involves a cell type, organ or tissue, and individual organelles in a cell and their proteomic analyses can tell us what kinds of proteins are expressed during plant growth and development. Proteomics is an essential part of plant proteome investigation, and that forms a base for extended proteomic studies, such as those involving protein changes due to unfavorable conditions for plant (Agrawal et al. 2005). Consequently, large sets of integrative data have been acquired and currently this information about proteins and metabolites involved in developmental control and environmental responses providing a great assistance in further research (Wienkoop et al. 2010).

\section{Proteome profiling of grapevine}

Differential expression profiling is one of the key technologies of the genomic century. The implementation of techniques for global analysis and comparison of whole genomes and/or proteomes, from disease and normal tissues, was an enormous step toward understanding of biological processes in general and disease/stress biology in particular. However, in order to get an insight to complex biological processes, genome analysis had to be complemented by technologies for comprehensive proteome analysis.

An experiment typical for proteomic study starts with cell protein extraction, even though such studies can be particularly challenging. Problem is that plant cells are rich not only in cell wall polysaccharides and polyphenols, but also in number of proteases that can degrade studied samples. Subsequently it is possible, that ascendancy of certain proteins can complicate the study of other, less abundant proteins. Next step is phase of separation, in which gel-free, in addition to 2-DE based platforms, and second-generation quantitative proteomic techniques- microarray are used (Patton et al. 2002, Quirino et al. 2010). While gel proteomics have been applied to a large number of post-translational modifications and expression proteomics studies, the technique still limits the range of proteins that can be analyzed. Approaches used for precise large-scale quantification and widespread identification are high throughput

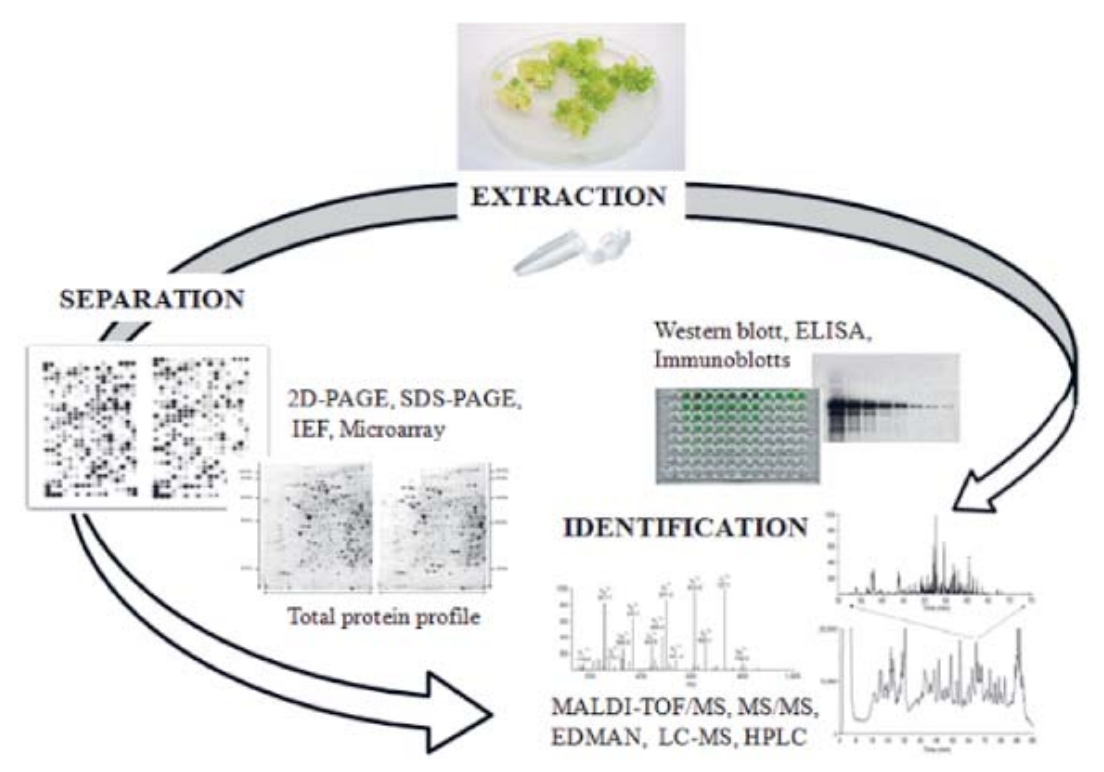

Fig. 2. Basic scheme of proteome profiling (Čarná et al. unpublished figure). 
shotgun proteomics, mass spectrometry and ionization methods (Wright et al. 1999) (Fig. 2).

It is not a matter of which protocol and technique is the best or should be used as it has been clearly shown that each one takes you to a minimal part of the total proteome, and all of them are complementary and necessary. Mapping the proteome with regards to not only amino acid sequences but also tertiary structures, cellular localizations and protein-component interactions or DNA is then the major task of the 21 st century.

Proteomic approaches and technologies are likely to have significant value for grape development. There is a potential to identify transcriptional, biochemical, molecular and genetic pathways that contribute to agronomic properties. Examples contain detection of transcriptional pathways, which are associated with berries quality and development

Tab. 1. The overview of plant samples, conditions and proteomic techniques/methods used in grapevine plant studies since 2008 .

\begin{tabular}{|c|c|c|c|c|}
\hline References & Tissue & Conditions & Separation & Identification \\
\hline 2008 Jellouli et al. & $\begin{array}{l}\text { stems, roots and } \\
\text { leaves }\end{array}$ & salt treatment & 2D gels & $\begin{array}{l}\text { N-term } \\
\text { sequencing }\end{array}$ \\
\hline 2008 Marsoni et al. & calluses & $\begin{array}{l}\text { embryogenesis and non } \\
\text { embryogenesis }\end{array}$ & 2D gels & LC-MS/MS \\
\hline 2008 Negri et al. & skins & five stages of ripening & $2 \mathrm{D}$ gels & LC-MS/MS \\
\hline 2008 Pesavento et al. & seeds & varietal differentiation & - & MALDI \\
\hline 2008 Zhang et al. & $\begin{array}{l}\text { grape berry } \\
\text { plasm. membrane }\end{array}$ & three stages of ripening & 2D gels & MALDI-TOF \\
\hline $\begin{array}{l}2008 \text { Repka \& } \\
\text { Baumgartnerová }\end{array}$ & calluses & $\begin{array}{l}\text { auxin and cytokinin } \\
\text { habituation }\end{array}$ & microarray & - \\
\hline 2009 Ferri et al. & cell suspensions & chitosan treatment & 2D gels & $\begin{array}{l}\text { MALDI-TOF/ } \\
\text { MALDI-TOF-TOF }\end{array}$ \\
\hline 2009 Grimplet et al. & $\begin{array}{l}\text { skin, flesh and } \\
\text { seeds }\end{array}$ & water stress & 2D gels & $\begin{array}{l}\text { MALDI TOF/ } \\
\text { TOF }\end{array}$ \\
\hline $\begin{array}{l}2009 \text { Martinez-Esteso } \\
\text { et al. }\end{array}$ & cell suspensions & $\begin{array}{l}\text { methylated cyclodextrins } \\
\text { and methyl jasmonate } \\
\text { treatments }\end{array}$ & 2D gels & $\begin{array}{l}\text { MALDI-TOF and } \\
\text { LC-MS/MS }\end{array}$ \\
\hline 2009 Wang et al. & berries & $\beta$-1,3-glucanase profiling & 2D immuneblots & MALDI-TOF \\
\hline 2009 Zhang et al. & calluses & $\begin{array}{l}\text { necrosis or not following } \\
\text { transformation with } \\
\text { Agrobacterium }\end{array}$ & 2D gels & MALDI-TOF \\
\hline 2010 Jellouli et al. & leaves and roots & salt treatment & $\begin{array}{l}\text { 2D gels, IEF, 2D } \\
\text { SDS PAGE }\end{array}$ & - \\
\hline 2010 Basha et al. & sap & pierce's disease & 2D gels & LC-MS/MS \\
\hline 2010 Giribaldi et al. & berries & ABA treatment & $2 \mathrm{D}$ gels & LC-MS/MS \\
\hline 2010 Zamboni et al. & berries & postharvest drying & 2D-DIGE & HPLC-MS \\
\hline 2010 Parrotta et al. & flowers and buds & bud development & 2D immunoblots & $\begin{array}{l}\text { anti- } \alpha \text { and anti- } \beta \\
\text { tubulin antibodies }\end{array}$ \\
\hline 2011 Zhao et al. & calluses & $\begin{array}{l}\text { A. tumefaciens- mediated } \\
\text { treatment }\end{array}$ & 2-D gels & MALDI-TOF/MS \\
\hline 2011 Giribaldi et al. & berries & $\begin{array}{l}\text { phloem-limited } \\
\text { viruses treatment }\end{array}$ & 2D gels & $\begin{array}{l}\text { MALDI-TOF/ } \\
\text { /TOF-MS }\end{array}$ \\
\hline $\begin{array}{l}2011 \text { Martinez-Esteso } \\
\text { et al }\end{array}$ & cell suspensions & $\begin{array}{l}\text { methylated cyclodextrins } \\
\text { and methyl jasmonate } \\
\text { treatments }\end{array}$ & DIGE & nLC-MS/MS \\
\hline $\begin{array}{l}2011 \text { Sharathchandra } \\
\text { et al. }\end{array}$ & cell suspensions & regulation of ripening & IEF, SDS PAGE & MALDI-TOF/MS \\
\hline $\begin{array}{l}2011 \text { Margaria \& } \\
\text { Palmano }\end{array}$ & berries & $\begin{array}{l}\text { 'flavescence dorée' } \\
\text { phytoplasma treatment }\end{array}$ & 2D gels, IEF & MALDI-TOF-TOF \\
\hline 2011 Yang et al. & tissue & Xylella fastidiosa treatment & 2D PAGE & LC-MS-MS \\
\hline 2012 Milli et al. & leaves & $\begin{array}{l}\text { Plasmopara viticola } \\
\text { treatment }\end{array}$ & $\begin{array}{l}\text { 2D PAGE, } \\
\text { Western Blot }\end{array}$ & $\begin{array}{l}\text { nanoHPLC-ESI- } \\
\text {-MS/MS }\end{array}$ \\
\hline 2012 Yao et al. & leaves & $\begin{array}{l}\text { Mn-induces resistance } \\
\text { to Powdery Mildew }\end{array}$ & DIGE & - \\
\hline
\end{tabular}


(sugar metabolits, organic acids, flavonoids, etc.) and disease resistance (specific resistance genes and downstream transcriptional pathways (da Silva et al. 2005). Analysis used for separation and identification of these proteins extracted from various grapevine tissues or cells are listed in Table 1.

In the beginning of Vitis proteome study, attention was focused mostly on physiological and biochemical processes like defense responses (Repka 2006), development of ripening (Deytieux et al. 2007, Giribaldi et al 2007, Negri et al. 2008, Zhang et al. 2008, Sharathchandra et al. 2011), somatic embryogenesis (Marsoni et al. 2008), varietal differentiation (Pesavento et al. 2008) and bud development (Parrotta et al. 2010), where uses of different profiling methods were shown not only protein composition, but also their function was detected. Results from studies dealing with the biochemical and physiological processes that drive grape development showed, that spots detected by 2D, SDS, PAGE gels and analyzed by MALDI-TOF/LCMS-MS, represented proteins grouped into eight functional categories, mainly involved in transport, metabolism, stress-induction, signal transduction, and protein synthesis (Table 1).

\section{Abiotic stress/elicitors}

In last few years, researchers have focused their attention mainly on phytopathology. This important approach of understanding particular response to infection includes observing biomolecules/ proteins made up by the response accumulate to concentrations that are biologically relevant to defense. To date, the most effort has been focused on the induction of grapevine resistance by increase of PR proteins number, including chitinase and $\beta$-1,3-glucanases (Wang et al. 2009). This effort is targeted on treatment with a wide scale of abiotic (Jellouli et al. 2008, 2010 Martinez-Esteso et al. 2009, 2011) and biotic elicitors (Yang et al. 2011, Milli et al. 2012, Yao et al. 2012).

One of the first studies, published in 2005, on grape adaptability to abiotic stress was study of time course response to herbicide treatment on in vitro cultivated shoots, roots and leaves using proteome techniques. The results indicated that Rubisco, plant leaves protein, is subjected to fragmentation after treatment, and antioxidant proteins are induced, such as those belonging to photorespiration. The carbon flux is altered, and plant defenses are stimulated, as revealed by the increase in the pathogenesis related protein 10 (PR10) isoforms (Castro et al. 2005). Another article about abiotic stress has reported about the salt stress-responsive proteins (SRP) in grapevine. This study shows that salt spreads systemically. Evidence is a presence of SRP in the different plant organs. Short-term salt treatments of roots and leaves also revealed a presence of these proteins with $98 \%$ similarity to PR10 protein (Jellouli et al. 2008, 2010). PR10 protein has been already observed previously to be expressed in mature berry skin and increased in abundance during the later stages of ripening and is thought to play a role in berries protection (Negri et al. 2008). In order to obtain information on protein expression changes in grape berry tissues, the response to well-watered and water-deficit stress conditions was performed by a comparative proteome analysis. Water-deficit stress led to tissue-specific changes in protein expression. The skin showed increased abundance of proteasome, reactive oxygen detoxification enzymes, and selected enzymes involved in flavonoid biosynthesis (polyphenol oxidase), whereas pulp tissues showed increased in glutamate decarboxylase, PR proteins, and methionine synthase (Grimplet et al. 2009). More recently, analysis of changes in the expression of 67 grape skin proteins were monitored from maturation to fully ripe berries of $V$. vinifera showing that many proteins with abiotic stress responses were developmentally regulated (Negri et al. 2008).

Induction of defense mechanisms occurs not only after affecting plant cells by abiotic factor (wetness, drought, salinity, etc.), but also by a plethora of (a) biotic molecules - elicitors. This observation was moved further by using proteomic-based strategies. The effect of chitosan-elicitor on grapevine proteome was studied by Ferri et al. 2009. Analysis of grapevine cell suspension showed that the amount of 73 proteins consistently changed after chitosan treatment and synthesis of stilbene synthase proteins and accumulation of trans-resveratrol ( $t R$ ) was recorded. It was also significant increase of the expression of the pathogen-related protein10 family recorded. The elicitation effect had been studied also after affecting grapevine cell suspension by methylated cyclodextrins (MBCD) and methyl jasmonate (MeJA) (Martinez-Esteso et al. 2009, 2011). In 2009 twenty-five of the 39 spots differentially expressed in 2-D gels were identified and found to be encoded by 10 different genes: three secretory peroxidases, chitinase-III, $\beta$-1,3glucanase, thaumatin-like, SGNH plant lipase-like, NtPR27-like, xyloglucan endotransglycosylase and subtilisin-like protease. Most of them belong to the pathogenesis-related type proteins and activators of systemic acquired resistance (SAR). In 2011 following study was published, where the aim was investigation of trans-resveratrol accumulation in response to both elicitors used before. The $t R$ biosynthetic pathway enzymes were up-regulated by MBCD alone or combined with MeJA, but not 
by treatment with MeJA alone. Seven spots contained stilbene synthase encoded by four different isogenes (Martinez-Esteso et al. 2011). It was similar response to abiotic elicitors as was published by Ferri et al. 2009. There are also some studies performed on fruits-berries. However, berry tissues contain large amounts of secondary metabolites, especially phenolic compounds, which severely interfere with protein extraction and electrophoresis separation. The special protocol was used, PVPP (polyvinyl polypyrrolidone)/TCS-based protein extraction, to extract and analyze 760 protein spots. This protocol combine with 2D immunoblots validated presence of $\beta$-1,3-glucanase in higher abundance in berry skins than in pulps, and in red berries than in white berries. Therefore, $\beta$-1,3-glucanase displays a tissue-specific expression (Wang et al. 2009). On the other hand, study confirms, that preferential accumulation of $\beta$-1,3-glucanase in skins may be relevant to berry ripening. The control of ripening of grapevine fruit is still a matter of debate, but several lines of evidence point to an important role for the hormone abscisic acid (ABA). The ABA is a well-known stress hormone and its biosynthesis, signaling, and molecular effects are triggered under water-, salt-, and cold-stress. The effect of ABA treatment was studied using 2DE proteomic approach. Results showed that ABA affected ripening-related proteins $\left(\mathrm{GIN}_{1}, V v L A R 2, V v A N\right)$, stress-related proteins (peroxidase, chitinase, lipoxygenase), signal transduction and caused general rearrangement of metabolism (Giribaldi et al. 2010).

Investigation of plant tumorigenesis is a way to clarify the mechanisms of systemic control of plant cell division and differentiation (Dodueva et al. 2007). One of the most known tumor formation is caused by Agrobacterium sp. Agrobacterium tumefaciens- mediated transformation is necessary for gene function studies of grapevine. The general proteomic profile to response of grapevine to A. tumefaciens- mediated transformation was examined by 2D electrophoresis and MALDI-TOF-MS analysis after co-cultivation of grapevine embryogenic callus (EC) with A. tumefaciens (Zhang et al. 2009, Zhao et al. 2011). Analysis of over 1100 protein spots identified the proteins significantly up-regulated $3 \mathrm{~d}$ after inoculationPR10 protein, resistance protein Pto, secretory peroxidase, cinnamoyl-CoA reductase and different expression regulators; down-regulated proteins were ascorbate peroxidase, tocopherol cyclase, Hsp 70 and proteins involved in the ubiquitin associated protein-degradation pathway (Zhang et al. 2009, Zhao et al. 2011). Results revealed that agrobacterial transformation significantly inhibits the reactive oxygen species ROS-removal system of cells, energy metabolism of mitochondria and the protein-deg- radation machinery for misfolded proteins. On the other hand, the apoptosis signaling pathway and hypersensitive response are strengthened, which might partially clarify the low efficiency and severe EC necrosis in grape transformation (Zhao et al. 2011).

\section{Biotic elicitors}

The first in vivo study was published in 2010 by Basha, who demonstrated effect of Pierce's disease (caused by bacterium Xylella fastidiosa) on PD-tolerant and PD-susceptible Vitis. Result was composition of protein profile induced by this biotic infection. LC-MS/MS spectrometry analysis of these proteins revealed their similarity to $\beta$-1,3-glucanase, peroxidase, and a subunit of oxygen-evolving enhancer protein 1, which are known to play role in defense and oxygen generation (Basha et al. 2010). Five $V$. vinifera proteins and five homologous proteins were identified by their differential expression at different developmental stages of tissue in these infected genotypes. A thaumatin-like protein and the PR10 from both genotypes were found to be up-regulated in response to Xf-infection (Yang et al. 2011).

The most widespread and also most tested are also viruses (GLRaV-1), (GVA) and Rupestris stem pitting associated virus ( $\mathrm{RSPaV})$. The first study about investigation on agronomic performance, fruit texture and composition, proteomics changes occurring in berries of virus-infected grapes grown in field conditions was reported by Giribaldi. The proteomic analysis of skin and pulp visualized about 400 spots. Virus infection mainly influenced proteins involved in metabolism of cell structure in the pulp, and proteins participated in response to oxidative stress in the berry skin. These results showed that infection increases a pulp degradation of cell wall and that it actually causes modifications in the skin structure (Giribaldi et al. 2011).

Not only viruses and bacteria but also other pathogens like fungi and phytoplasmas affect grape quality and productivity. 'Flavescence dorée' is a serious phytoplasma disease affecting grapevine in several European countries. Monitoring of infected protein expression profile of more tolerant "Nebiollo" has showed expression of stress-related proteins (43\%), changes in metabolism (21\%), protein fate (18\%), energy $(9 \%)$, cellular transport $(6 \%)$ and protein synthesis (3\%) (Margaria and Palmano 2011).

Plant-fungi interactions were analyzed on grapevine leaves 24, 48 and $96 \mathrm{~h}$ post infection with the downy mildew pathogen Plasmopara viticola. MS analyses identified 82 unique grapevine proteins differentially expressed after infection. Functional categories of general metabolism and stress re- 
sponse often included upregulated proteins, while downregulation is associated with proteins assigned to photosynthesis and energy production. Plant resistance was mostly associated with isoforms of different PR-10 proteins. A defense response in this view suggests a temporary breakdown accompanying the inception of disease. It was confirmed by gene expression analyses and by a western blot analysis of a PR-10 protein (Milli et al. 2012). Another view on this disease was about increase of grapevine resistance caused by Manganase. It was found that high leaf Mn concentrations $\left(<2500 \mu \mathrm{g} \mathrm{g}^{-1}\right)$ induced grapevine resistance to powdery mildew. Manganese is able to delay a pathogen spreading after powdery mildew (PM) inoculation, but in long-term basis it did not directly inhibit pathogen development. A high Mn concentration in grapevine caused small oxidative stress, but on the other hand it was deeply enhanced by PM stress. High leaf Mn concentration, as well as PM stress, significantly enhanced a concentration of salicylic acid (SA) and increased the expression of proteins involved in synthesis of ethylene and jasmonic acid (JA) - defense mediated signals. The excess of manganese also enhanced a proteins related to pathogen resistance, including a PR-like protein together with an NBS-LRR encoding resistance gene analogue, and a JOSL protein. The finding confirmed that high leaf Mn concentration in grapevine is able to trigger protective mechanisms against pathogens (Yao et al. 2012).

Changes in plant metabolism, leading to production of auxin and cell-division factors, suggest that habituation is due to the heritable expression of genes normally inactive in cultured cells. Habituation, relative to auxin, has been found to occur in a large number of plant species including sunflower (Henderson 1954), tobacco (Buiatti and Bennici 1970), maize (Hawes et al. 1985) and grapevine (Morel 1927). Grapevine calli planted on cytokinin (BAP) dependent medium induce this cellular change as well (Repka and Baumgartnerová 2008). For the first time, proteome profiling examines the molecular mechanisms of grapevine habituation (Repka and Baumgartnerová 2008). Proteome profiles of non-habituated and/or cytokinin and auxin habituated grapevine cell cultures was also examined. Non-habituated and habituated cell cultures 2-D maps showed existence of 55 protein spots displaying a differential expression pattern. There was confirmed a different protein pattern of these types of cultures and different expression level of individual proteins generated as the habituation process progressed. These results indicate profound metabolic transformation of these types of cells. Habituation for these growth factors in plant culture provides an experimental system ideally suited for studying how the production of these factors affects metabolic pathways in cell organization (Repka and Baumgartnerová 2008; Čarná et al. 2011).

\section{Interactomics}

Systems biology specifically combines the molecular components (transcripts, proteins, and metabolites) of an organism and incorporate them into functional networks or models designed to explain its molecular connections and dynamic activities. While many of the functions of individual parts are unknown or not well defined, their biological role can sometimes be inferred through association with other known parts, providing a better understanding of the biological system as a whole. On a systemwide scale the explanation requires three levels of information:

- structural annotation (identification of the components) and functional annotation (characterization of components identity);

- identification of interacting molecules;

- characterization of the transcripts, proteins, and metabolites behavior under various conditions (Albert 2007, Grimplet et al. 2009, Richards et al. 2010).

Consequently, term 'interactomics' describes the discipline, which studies how molecules are functionally linked in living organisms, and the consequences of their interactivity.

The slightly different meanings of word 'interactome' can be found in the literature. Interactome is generally defined as the whole set of molecular interactions in cells. Molecular forces and interactions can occur not only between molecules belonging to different biochemical families (proteins, nucleic acids, lipids, etc.), but also within a given family. Connection of these molecules by physical interactions creates large biomolecular interaction networks, which are classified by the nature of the compounds involved. On the other hand, most commonly is interactome an abstraction describing an incomplete set of protein complexes that might possibly form under a variety of conditions if the relevant protein partners have been expressed in any given cell type and located in compatible cell compartments (Gavin et al. 2006, Krogan et al. 2006).

Over the course of a few years, the field of interactomics has moved from the first high-throughput studies, through the tentative assembly of model organism sub-interactomes, to whole interactome assemblies and, most recently, cross-species comparisons of full interactomes. Within the past couple of years, applications have started emerging, such as functional indexing of organelles, identifying new 


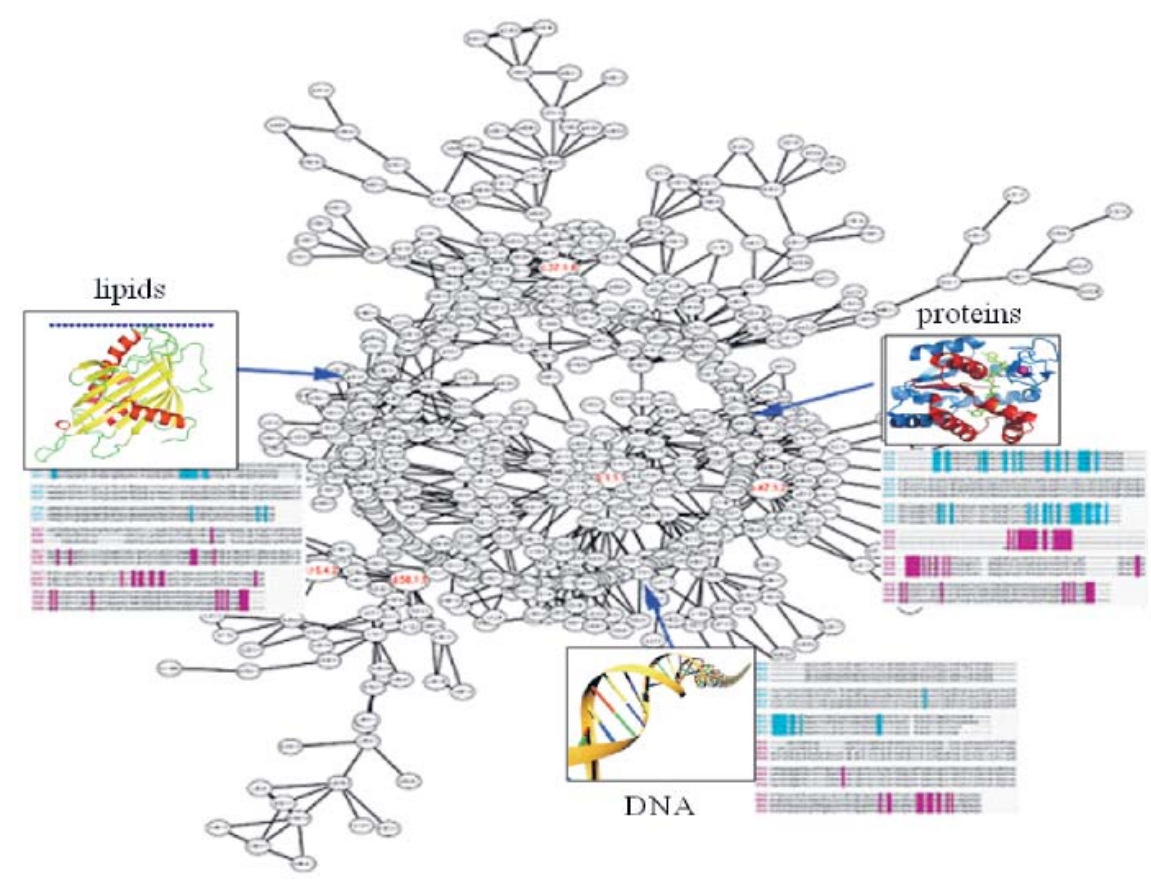

Fig. 3. Scheme of interactome network (an interaction network made by PSIMAP: http://psimap.org).

disease genes, unraveling signaling pathways and evolutionary analysis. Comparative interactomics denotes the process of comparing also interactions that occur in different cell conditions owing to environmental or genetic changes (Hinsby et al. 2006). However, as was pointed out by von Mering et al. (2007) there is still a large gap between our knowledge on proteomes and our knowledge on interactomes, with the latter lagging far behind the former. To answer a question about fundamental plant development much experimental work should be done, along with development of bioinformatics techniques and compartment-specific interactomics (Sharan and Ideker 2006).

\section{Grapevine interactome}

The first plant to have its genome fully sequenced was the weed Arabidopsis thaliana L., and this was accomplished in 2000 (Initiative 2000). In addition to that of A. thaliana, among the first plant genomes fully sequenced were three others: rice (Project 2005), poplar (Tuskan et al. 2006) and grape (Jaillon et al. 2007). Of the four fully sequenced plant genomes, the grape genome (cv- Pinot Noir) was the last to become available through the efforts of two separate groups (Velasco et al. 2007, Doddapaneni et al. 2008).

Based on the protein domain interaction analysis fundamental differences among eukaryotic interactomes were found (Repka and Baumgartnerová 2008). It was confirmed that all predicted protein family interactomes (the full set of protein family interactions within a proteome) of grapevine and other 5 species (yeast, Drosophila, worm, Arabidopsis and human, Fig. 4) are scale-free networks, they share a small core network comprising 16 protein families related to essential cellular functions involved predominantly in pathogenesis, apoptosis and plant tumorigenesis, as well. There is molecular evidence suggesting that grapevine cells were originated from heritable alternations in the pattern of gene expression (Fig. 5, Repka and Baumgartnerová 2008).

There is expectation that a variety of interesting questions will be answered by comparing interac-

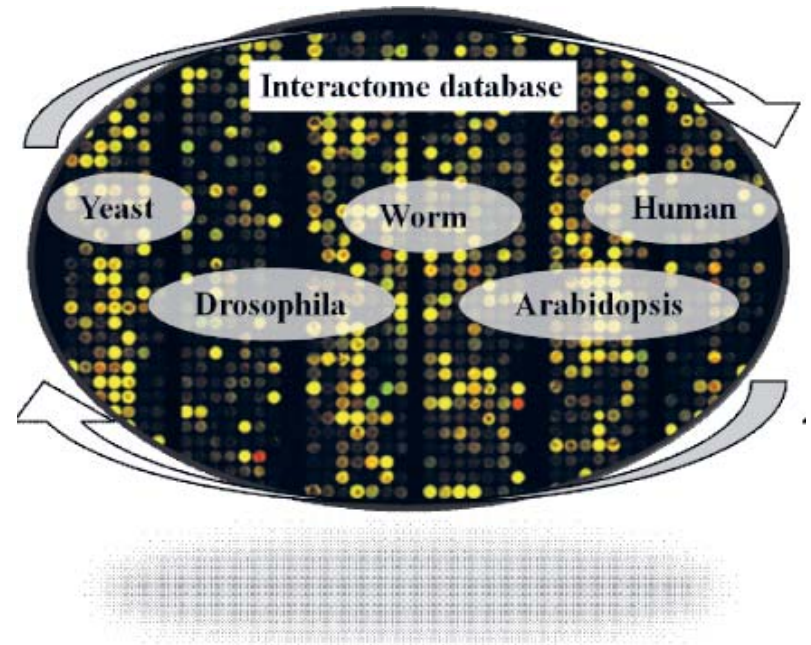

Fig. 4. Networks in Cellular Systems. To date, cellular networks are most available for the "super -model" organisms yeast, worm, fly, plant and human (Čarná et al. unpublished figure). 


\section{Interactome network graph}

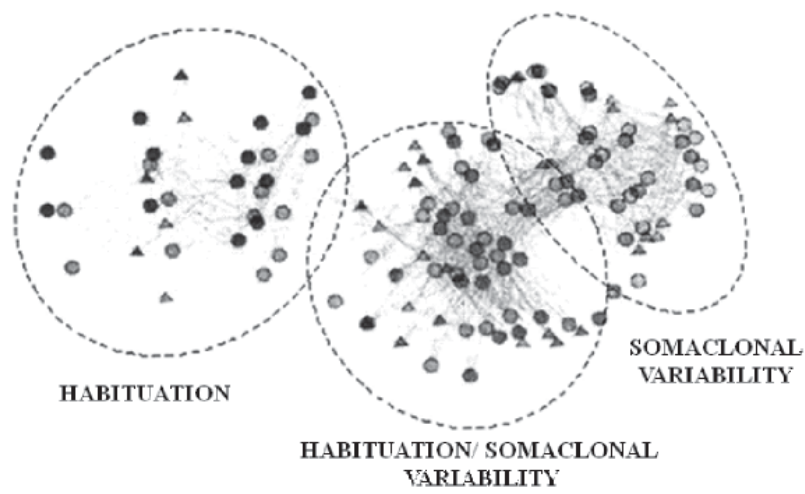

Fig. 5. Comparative interactomic of grapevine. The cartoon representation of six interactomes in the protein interaction space

(Repka and Baumgartnerová 2008).

tomes and for this reason is interactomic currently one of the fastest developing fields in molecular biology (Kiemer and Cesareni 2007).

\section{Conclusion}

The application of such knowledge throughout the world should lead to grape improvement and subsequently to improve viticultural practices and define a molecular breeding. Approaches such as proteomics and interactomics will facilitate understanding of processes of $V$. vinifera cultivars, with the goal of improving agronomic yield while preserving traditional grapevine qualities.

\section{Acknowledgement}

This research supported by a grant of the Slovak Grant Agency (VEGA 2/0200/10).

\section{References}

Agrawal GK, Yonekura M, Iwahashi Y, Iwahashi H, Rakwal R (2005) J. Chromatogr. B. 815: 109-123.

Abhilash M (2009) The Internet Journal of Genomics and Proteomics. 4: DOI: 10.5580/1787.

Albert R (2007) Plant Cell 19: 3327-3338.

Basha SM, Mazhar H, Vasanthaiah HK (2010) Appl. Biochem. Biotechnol. 160:932-44.

Buiatti M, Bennici A (1970) Rend. Accad. Naz. Lincei. 48: 261-269.

Castro AJ, Carapito C, Zorn N, Magné C, Leize E, Van Dorsselaer A (2005) J. Exp. Bot. 56:2783-95.

Čarná M, Repka V, Šturdík E (2011) Agriculture 57: 129-136.

da Silva FG, Iandolino A, Al-Kayal F, Bohlmann MC, Cushman MA, Lim H, Ergul A, Figueroa R, Kabuloglu EK, Osborne C, Rowe J, Tattersall E, Leslie A, Xu J, Baek JM, Cramer GR, Cushman J.C., Cook DR (2005) Plant Physiology 139: 574-597.
Deytieux C, Geny L, Lapaillerie D, Claverol S, Bonneu M, Donèche B (2007) J. Exp. Bot. 58:1851-62.

Doddapaneni H, Lin H, Walker MA, Yao J, Civerolo EL (2008) BMC Plant Biol. 8: 23.

Dodueva IE, Frolova NV, Lutova LA (2007) Transgenic Plant J. 1: 17-34.

Ferri M, Tassoni A, Franceschetti M, Righetti L, Naldrett MJ, Bagni N (2009) Proteomics 9: 610-24.

Gavin AC, Aloy P, Grandi P, Krause R, Boesche M, Marzioch M, Rau C, Jensen LJ, Bastuck S, Dümpelfeld B, Edelmann A, Heurtier MA, Hoffman V, Hoefert C, Klein K, Hudak M, Michon AM, Schelder M, Schirle M, Remor M, Rudi T, Hooper S, Bauer A, Bouwmeester T, Casari G, Drewes G, Neubauer G, Rick JM, Kuster B, Bork P, Russell RB, Superti-Furga G (2006) Nature. 440: 631-636.

Giribaldi M, Perugini I, Sauvage FX, Schubert A (2007) Proteomics 7:3154-70.

Giribaldi M, Gény L, Delrot S, Schubert A (2010) J Exp. Bot. 61: 2447-2458.

Giribaldi M, Purrotti M, Pacifico D, Santini D, Mannini F, Caciagli P, Cavallarin L, Giuffrida MG, Marzachi C (2011) J Proteomics 75: 306-15.

Grimplet J, Wheatley MD, Jouira HB, Deluc LG, Cramer GR, Cushman JC (2009) Proteomics 9: 2503-28.

Hawes MC, Sharpe DZ, Plata MI, Pueppke SG, Chourey PS (1985) Plant Sci. 40: 197-202.

Henderson JHM (1954) Ann. Biol. 30: 329-348.

Hinsby AM, Kiemer L, Andersen JS, Mann M, Brunak S (2006) Mol Cell. 22: 285-295.

Initiative TAG (2000) Nature. 408: 796-815.

Jaillon O, Aury JM., Noel B, Policriti A, Clepet C, Casagrande A, Choisne N, Aubourg S, Vitulo N, Jubin C, Vezzi A, Legeai F, Hugueney P, Dasilva C, Horner D, Mica E, Jublot D, Poulain J, Bruyere C, Billault A, Segurens B, Gouyvenoux M, Ugarte E, Cattonaro F, Anthouard V, Vico V, Del Fabbro C, Alaux M, Di Gaspero G, Dumas V, Felice N, Paillard S, Juman I, Moroldo M, Scalabrin S, Canaguier A, Le Clainche I, Malacrida G, Durand E, Pesole G, Laucou V, Chatelet P, Merdinoglu D, Delledonne M, Pezzotti M, Lecharny A, Scarpelli C, Artiguenave F, Pe ME, Valle G, Morgante M, Caboche M, Adam-Blondon AF, Weissenbach J, Quetier F, Wincker P (2007) Nature 449: 463-467.

Jellouli N, Jouira HB, Skouri H, Ghorbel A, Gourgouri A, Mliki A (2008) J. Plant Physiol. 165: 471-81.

Jellouli N, Jouira HB, Daldoul S, Chenennaoui S, Ghorbel A, Salem AB, Gargouri A (2010) Plant Molecular Biology Reporter 28: 1-8.

Jorrín-Novo JV, Maldonado AM, Echevarría-Zomeno S, Valledor L, Castillejo MA, Curto M, Valero J, Sghaier B, Donoso G, Redondo I (2009) J Proteomics 72: 285-314.

Kiemer L, Cesareni G (2007) TRENDS in Biotechnology 25: 448-454.

Krogan NJ, Cagney G, Yu H, Zhong G, Guo X, Ignatchenko A, Li J, Pu S, Datta N, Tikuisis AP, Punna T, Peregrín-Alvarez JM, Shales M, Zhang X, Davey M, Robinson MD, Paccanaro A, Bray JE, Sheung A, Beattie B, Richards DP, Canadien V, Lalev A, Mena F, Wong P, Starostine A, Canete MM, Vlasblom J, Wu S, Orsi C, Collins SR, Chandran S, Haw R, Rilstone JJ, Gandi K, Thompson NJ, Musso G, St Onge P, Ghanny S, Lam MH, Butland G, Altaf-Ul AM, Kanaya 
S, Shilatifard A, O'Shea E, Weissman JS, Ingles CJ, Hughes TR, Parkinson J, Gerstein M, Wodak SJ, Emili A, Greenblatt JF (2006) Nature. 440: 637-643.

Margaria P, Palmano S (2011) Proteomics 11: 212-224.

Marsoni M, Bracale M, Espen L, Prinsi B, Negri AS, Vannini C (2008) Plant Cell Rep. 27:347-56.

Martinez-Esteso MJ, Sellés-Marchart S, Vera-Urbina JC, Pedreno MA, Bru-Martinez R (2009) J. Proteomics 73: 331-41.

Martinez-Esteso MJ, Sellés-Marchart S, Vera-Urbina JC, Pedreno MA, Bru-Martinez R (2011) J Proteomics 74: 1421-36.

Milli A, Cecconi D, Bortesi L, Persi A, Rinalducci AZ, Zamboni A, Zoccatelli G, Lovato A, Zolla L, Polverari A (2012) Journal of Proteomics 75 : 1284-1302.

Morel G (1927) C. R. Soc. Biol. 141: 280-282.

Negri AS, Prinsi B, Scienza A, Morgutti S, Cocucci M, Espen L (2008) J. Plant Physiol. 165: 1379-89.

Parrotta L, Cai G, Cresti M (2010) Planta 231:277-91.

Patton WF, Schulenberg B, Steinberg TH (2002) Curr. Opin. Biotechnol. 13: 321-8.

Pesavento IC, Bertazzo A, Flamini R, Vedova AD, De Rosso M, Seraglia R (2008) J. Mass Spectrom 43:234-41.

Project IRGS (2005) Nature 436: 793-800.

Quirino BF, Candido ES, Campos PF, Franco OL, Kruger RH (2010) Phytochemistry 71: 351-362.

Remmerie N, De Vijlder T, Laukens K, Dang TH, Lemière F, Mertens I, Valkenborg D, Blust R, Witters E (2011) Phytochemistry 72: 1192-1218.

Repka V (2006) Biologia Plantarum 50: 94-100.

Repka V, Baumgartnerová I (2008) Acta Agronomica Hungarica 56: 399-408.

Richards SE. Dumas ME, Fonville JM, Ebbels TMD, Holmes E., Nicholson JK (2010) Chemometrics and Intelligent Laboratory Systems 104: 121-131.

Sharan R, Ideker T (2006) Nat. Biotechnol. 24: 427-433.

Sharathchandra RG, Stander Ch, Jacobson D, Ndimba B, VivierSharathchandra MA (2011) PLoS One 6: e14708.

Siming L, Armstrong MA, Bertin N, Hui GF, Milstein S (2004) Science. 303: 540-543.

Tuskan GA, Difazio S, Jansson S, Bohlmann J, Grigoriev I, Hellsten U, Putnam N, Ralph S, Rombauts S, Salamov A, Schein J, Sterck L, Aerts A, Bhalerao RR, Bhalerao RP, Blaudez D, Boerjan W, Brun A, Brunner A, Busov V, Campbell M, Carlson J, Chalot M, Chapman J, Chen GL, Cooper D, Coutinho PM, Couturier J, Covert S, Cronk Q, Cunningham R, Davis J, Degroeve S, Dejardin A, Depamphilis C, Detter J, Dirks B, Dubchak I, Duplessis S, Ehlting J, Ellis B, Gendler K, Goodstein D, Gribskov M, Grimwood J, Groover A, Gunter L, Hamberger B, Heinze B, Helariutta Y, Henrissat B,
Holligan D, Holt R, Huang W, Islam-Faridi N, Jones S, Jones-Rhoades M, Jorgensen R, Joshi C, Kangasjarvi J, Karlsson J, Kelleher C, Kirkpatrick R, Kirst M, Kohler A, Kalluri U, Larimer F, Leebens-Mack J, Leple JC, Locascio P, Lou Y, Lucas S, Martin F, Montanini B, Napoli C, Nelson DR, Nelson C, Nieminen K, Nilsson O, Pereda V, Peter G, Philippe R, Pilate G, Poliakov A, Razumovskaya J, Richardson P, Rinaldi C, Ritland K, Rouze P, Ryaboy D, Schmutz J, Schrader J, Segerman B, Shin H, Siddiqui A, Sterky F, Terry A, Tsai CJ, Uberbacher E, Unneberg P, Vahala J, Wall K, Wessler S, Yang G, Yin T, Douglas C, Marra M, Sandberg G, Van de Peer Y, Rokhsar D (2006) The Science 313: $1596-1604$

Velasco R, Zharkikh A, Troggio M, Cartwright DA, Cestaro A, Pruss D, Pindo M, Fitzgerald LM, Vezzulli S, Reid J, Malacarne G, Iliev D, Coppola G, Wardell B, Micheletti D, Macalma T, Facci M, Mitchell JT, Perazzolli M, Eldredge G, Gatto P, Oyzerski R, Moretto M, Gutin N, Stefanini M, Chen Y, Segala C, Davenport C, Dematte L, Mraz A, Battilana J, Stormo K, Costa F, Tao Q, Si-Ammour A, Harkins T, Lackey A, Perbost C, Taillon B, Stella A, Solovyev V, Fawcett JA, Sterck L, Vandepoele K, Grando SM, Toppo S, Moser C, Lanchbury J, Bogden R, Skolnick M, Sgaramella V, Bhatnagar SK, Fontana P, Gutin A, Van de Peer Y, Salamini F, Viola R (2007) PLoS ONE 2: 1326.

von Mering C, Jensen LJ, Kuhn M, Chaffron S, Doerks T, Kruger B, Snel B, Bork P (2007) Nucleic Acids Res. 35: 358-362.

Wang W, Bianchi L, Scali M, Liu L, Bini L, Cresti M (2009) Acta Physiol. Plant 31: 597-604.

Wienkoop S, Baginsky S, Weckwerth WJ (2010) Proteomics. 73: 2239-48.

Wright JGL, Cazares LH, Leung SM, Nasim S, Adam BL, Yip TT, Schellhammer PF, Gong L, Vlahou A (1999) Protease Cancer and Prostatic diseases 2: 264-276.

Yang L, Lin H, Takahashi Y, Chen F, Walker M, Civerolo EL (2011) Physiological and molecular Plat Pathology 75: 90-99.

Yao YA, Wang J, Ma XM, Lutts S, Sun Ch, Ma J, Yang Y, Achal V, Xu G (2012) J. Exp. Bot. 63: 5155-5170.

Zamboni A, Di Carli M, Guzzo F, Stocchero M, Zenoni S, Ferrarini A, Tononi P, Toffali K, Desiderio A, Lilley KS, Pè ME, Benvenuto E, Delledonne M, Pezzotti M (2010) Plant Physiology 154: 1439-1459.

Zhang J, Ma H, Feng J, Zeng L, Wang Z, Chen S (2008) J. Exp. Bot. 59:2979-90.

Zhang J, Ma H, Chen S, Ji M, Perl A, Kovacs L (2009) Plant Sci. 177: 103-110.

Zhao F, Chen L, Perl A, Chen S, Ma H (2011) Plant Science 181: 485-495. 